\title{
プリント配線板の微小径穴あけ加エにおけるドリル回転数および工具摩耗が 切りくず排出性におよぼす影響
}

吉村 博仁 ${ }^{* 1}$, 片平 雄 ${ }^{* 2}$, 渡邊 英人 ${ }^{* 3}$, 山下 泰樹 ${ }^{* 4}$

\section{Study on effect of drilling rotational speed and tool wear on chip evacuation of micro drilling of printed circuit board}

\author{
Hiromi YOSHIMURA $^{* 1}$, Yu KATAHIRA ${ }^{* 2}$, Hidehito WATANABE ${ }^{* 3}$ and Taiju YAMASHITA* ${ }^{* 4}$ \\ ${ }^{* 1,},{ }^{4}$ Niigata University \\ 8050 Ikarashi2-cho, Nishi-ku, Niigata-shi, Niigata 950-2181, Japan \\ ${ }^{* 2}$ TOSHIBA Machine CO.,LTD. \\ 2068-3 Ooka, Numazu-shi, Shizuoka 410-8510, Japan \\ ${ }^{* 3}$ UNION TOOL CO \\ 2706-6 Togawa, Settaya-machi, Nagaoka-shi, Niigata 940-1104. Japan
}

Received 23 August 2015

\begin{abstract}
In recent years, needs for micro drilling are increasing, accompanying the development of higher wiring density of printed circuit board (PCB). When drilling PCB for the purpose of making the electric through holes, it has been said that the drill breakage is caused by being filled the chips of GFRP and copper of PCB in the drill flutes. Series of drilling tests of PCB have been carried out to investigate the shape of chips produced and the chips evacuation behavior out of drilling hole of the drill at the rotational speed of from $20 \times 10^{3} \mathrm{~min}^{-1}$ to $160 \times 10^{3} \mathrm{~min}^{-1}$. The chips evacuation behavior out of drilling hole of the drill is filmed by a high-speed motion camera and the shape of chips produced is observed by a microscope. The chips of GFRP are short and small pieces with an increase in the drilling rotational speed. The evacuation out of drilling hole of the drill is very well and both of maximum cutting torque and average cutting torque are decreasing with an increase in the drilling rotational speed. When drilled at rotational speed of $160 \times 10^{3} \mathrm{~min}^{-1}$, the chips of GFRP are long and large pieces, on the other hand, the chips of copper are short pieces, and chips evacuation out of drilling hole of the drill is almost not worse with an increase in the tool wear.
\end{abstract}

Key words : Printed circuit board, GFRP, Micro drilling, Chip evacuation, Shape of chip, Cutting torque

\section{1. 緒言}

パソコンや携帯電話に代表される電子機器の多くはプリント配線板（Printed circuit board : 以下 PCB）が内蔵さ れており，スルーホールと呼ばれる微小径の導通穴を用いて基板の上下で立体回路が形成されている. 近年の電 子機器の軽薄短小化や高性能化に伴い PCB 配線パターンも高密度化し, スルーホールも小径化かつ狭ピッチ化の 傾向にある. PCB は導電層である銅䇴層および絶縁層であるガラス繊維強化プラスチック (Glass fiber reinforced plastic：以下 GFRP）から構成される複合材料であるため, PCB のスルーホール穴あけは被削材としての銅馢層 および GFRP 層が同一切れ刃を用いて同時に切削される異材質加工である.さらには生産効率の向上を目的に PCB を複数枚重衫合わせて穴あけ加工される小径深穴加工のため，切りくず詰まりによってドリルが破損するこ とが多く，切りくず排出性向上が重要な課題である．ドリル直径が通常寸法で被削材が金属材料の穴あけ加工で

\footnotetext{
No. 15-00463 [DOI: 10.1299/transjsme.15-00463], J-STAGE Advance Publication date : 26 January, 2016

*1 正員, 新潟大学（干950-2181 新潟県新潟市西区五十嵐 2 の町 8050)

*2 東芝機械(株) （干410-8510 静岡県沼津市大岡 2068-3）

*3 正員，ユニオンツール（株）（†940-1104 新潟県長岡市摂田屋町字外川 2706-6）

*4 新潟大学

E-mail of corresponding author: yoshimura@mot.niigata-u.ac.jp
} 
は，切りくず形状や切りくず排出に関する解析的あるいは実験的研究が数多くなされている (Mellinger et al., 2003，中山，小川，1985）。ドリル直径が小径の金属材料あけ加工においては，切りくず詰まりがドリル折損の主 原因であること，およびステップフィードにより切りくずを分断させることが切りくず排出において効果がある ことが報告されている（Heineman et al., 2006）。

一方, PCB の小径穴あけ加工においては，穴あけ深さが深くなると切りくず詰まりが発生し切削トルクが増大 することでドリル折損に至ることが報告されている（大幸他，1994，岩田他，1982，大久保他，1985，小野他， 1992, Subramanian and Cook, 1977, 渡邊他，2009). PCB の小径穴あけに対しては切りくず詰まりがドリル折損 に大きな影響を与えているもかかわらず, 切りくず排出性や切りくず形状といった切りくずそのものに関する研 究はほとんど見当たらない.これはPCB の小径穴あけ加工の際に排出される切りくずの大きさは極めて小さく, 切りくず採取や観察が非常に困難であることが理由のひとつであると考えられる.

本研究では, 直径 $0.25 \mathrm{~mm}$ の超硬ドリルを用いて PCB のスルーホール穴あけ加工をおこない, 切削条件および 工具摩耗が切りくず排出性や切りくず形状におよぼす影響を検討し, 切りくず詰まりが生じる切削機構を明らか にする 具体的には, 4 枚重ねの PCB を用いて, ドリル送り量を $0.02 \mathrm{~mm} / \mathrm{rev}$ 一定としドリル回転数が $20 \times 10^{3} \mathrm{~min}^{-1}$ から $160 \times 10^{3} \mathrm{~min}^{-1}$ の範囲で穴あけ加工実験を行い，切りくず排出状況は高速度カメラを用いて撮影し，排出され た切りくず形状は顕微鏡を用いて観察する．さらには，穴あけ加工中の切削トルクを測定し，切りくず排出性や 切りくず形状との関係を検討する.

\section{2. 実験方法と実験条件}

表 1 は実験に用いる被削材である PCB の主な仕様を示す. 図 1 はPCB1 枚の断面模式図を示している. GFRP 層の上下には厚さ $12 \mu \mathrm{m}$ の銅筞層をそれぞれ積層させており, PCB の 1 枚あたりの板厚は $0.8 \mathrm{~mm}$ である. 実験に は低熱膨張・難燃化や弾性率の向上を目的として, シリカ $\left(\mathrm{SiO}_{2}\right)$ や水酸化アルミニウム $\left(\mathrm{Al}(\mathrm{OH})_{3}\right)$ などの無機 フィラーが 30vol\%以上充てんされている PCB（三菱ガス化学(株：CCL-HL832HS）を用いる.

Table 1 Specification of PCB

\begin{tabular}{c|c}
\hline \multirow{2}{*}{ Material } & $\begin{array}{c}\text { Glass cloth and resin base copper-clad } \\
\text { Laminate }[\text { Mitsubishi : CCL-HL832HS] }\end{array}$ \\
\hline $\begin{array}{c}\text { Copper } \\
\text { layer }\end{array}$ & Thickness : $0.012 \mathrm{~mm} /$ layer \\
\hline Height & $\mathrm{t} 0.8 \mathrm{~mm} / \mathrm{panel}$ \\
\hline
\end{tabular}

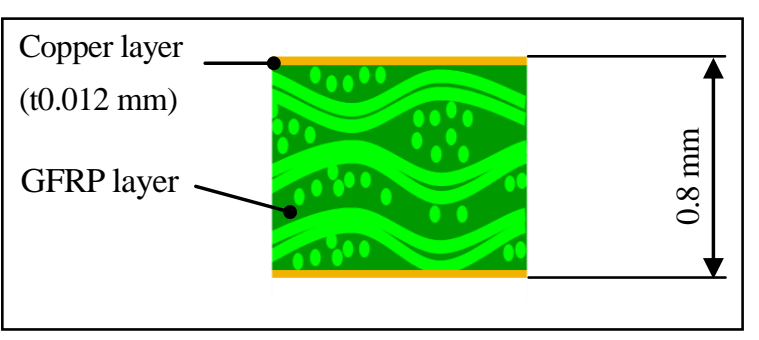

Fig. 1 Schematic illustration of cross section of PCB

図 2 は穴あけ加工実験装置の模式図を示す，穴あけ加工実験には最高回転数 $160 \times 10^{3} \mathrm{~min}^{-1}$ の AC モータ駆動工 アベアリングスピンドルを搭載した汎用 PCB 用 NC 穴あけ加工機（日立ビアメカニクス社 : ND-1V212）を用い る. 実験機のテーブル上にバックアップボードを載せ，その上に PCB を 4 枚重ね合わせて固定し，穴あけ実験を おこなう。バックアップボードの材質はベークライトを用いる. プレッシャーフットは穴あけ加工機のスピンド ル固定側に取り付けられている. プレッシャーフットの先端にはブッシュが取り付けられ，被削材である 4 枚重 ねの PCB およびバックアップボードを押さえ付け，穴あけ加工中の浮き上がりを防止している. 切削トルクを測 定する場合はプレッシャーフットのブッシュで押さえつけた場合と同様の浮き上がり防止効果を得るために， 4 枚重ねの PCB およびバックアップボードは圧電型動力計に 4 カ所ボルト締めされている. このため, プレッシャ ーフットの有無が切削トルク測定におよぼす影響は無視できると考える.

プレッシャーフットとバキュームホースとの間に市販の掃除機用集塵フィルタを挿み込み，穴女け加工後の切 りくずを採取する. PCB 切りくずは，ひとつの切削条件ごとに 20 穴分を採取し GFRP 切りくずおよび銅簿切り くずに分類する. それぞれの切りくずは，切りくず形状観察や切りくず長さ測定を顕微鏡（デジタルマイクロス コープ，KEYENCE 社，VHX-900）を用いて行う．PCB 穴あけ加工は，4枚重ねのPCB を穴あけ完了するまでの 
過程および穴あけ完了後に加工穴から戻寸過程の 2 つに大き分けられる. 前者を穴あけ過程, 後者を戻し過程 と呼び，穴あけ過程と戻し過程を合わせて穴あけ加工 1 サイクルと呼ぶ．穴あけ過程における穴入り口部から排 出される切りくず, および戻し過程におけるドリルに付着した切りくずやドリルから脱落する切りくずは, 高速 度カメラ（ナックイメージテクノロジー社，MEMRECAM fx-K4）を用いて観察する.

図 3 に示寸ように, 穴あけ加工 1 サイクル中の切削トルクは圧電型動力計（Kistler 社 : 9329A）を用いて測定 される. 動力計の切削トルク信号は, ローパスフィルタ（カットオフ周波数 $\mathrm{f}_{\mathrm{c}}=1.0 \mathrm{kHz}$ ）を介し, 切削トルク測定 において電気的および機械的ノイズと考えられる高周波成分を除去している.

高速度カメラ撮影および切削トルク測定の際は，切りくず吸引装置は作動せずに穴あけ加工される．切りくず 吸引装置は, 加工穴外部へ排出されて PCB 基板上に堆積した切りくずを除去するのが目的であり, 切りくず吸引 装置の作動の有無が切りくず排出性や切削トルク測定におよぼす影響はないことが確認されている.このため, 切りくず吸引装置の有無が高速度カメラを用いた切りくず排出状況観察および切削卜ルク測定におよぼす影響は 無視できると考える.

図 4 は GFRP 切りくず 1 個の切りくず長さの測定方法を示す. 切りくずの端と端とを結ぶ直線が切りくず上を 通過する場合（図４（a）），および切りくずの端と端とを結ぶ直線が切りくず上から外れる場合（図 4（b））に 分けられる. 前者の場合は端と端とを結ぶ直線距離を用いて 1 個の切りくず長さ $\ell(\mathrm{GF})$ を算出する. 後者の場合 は，切りくずの曲がった部位で分割しそれぞれの直線距離 $\ell_{1}(\mathrm{GF}), \ell_{2}(\mathrm{GF}), \cdots, \ell_{\mathrm{n}}(\mathrm{GF})$ を足し合わせて切りくず 1 個の切りくず長さ $\ell(\mathrm{GF})=\ell_{1}(\mathrm{GF})+\ell_{2}(\mathrm{GF})+\cdots+\ell_{\mathrm{n}}(\mathrm{GF})$ を算出する. 次に, 切削条件ごとに採取された 20 穴分 の切りくずの中から切りくず長さが長い方から 5 個の切りくずを選択し, それらの算術平均值を求め, その值を 切削条件における切りくず長さ $\ell_{\mathrm{m}}(\mathrm{GF})$ と定義する. 図 5 は銅馢切りくず 1 個の切りくず長さの測定方法を示す. 銅簿切りくずについても GFRP 切りくずと同様に切りくず 1 個の切りくず長さ $\ell(\mathrm{Cu})$ を算出し, それぞれの切削 条件における切りくず長さ $\ell_{\mathrm{m}}(\mathrm{Cu})$ が定義される.

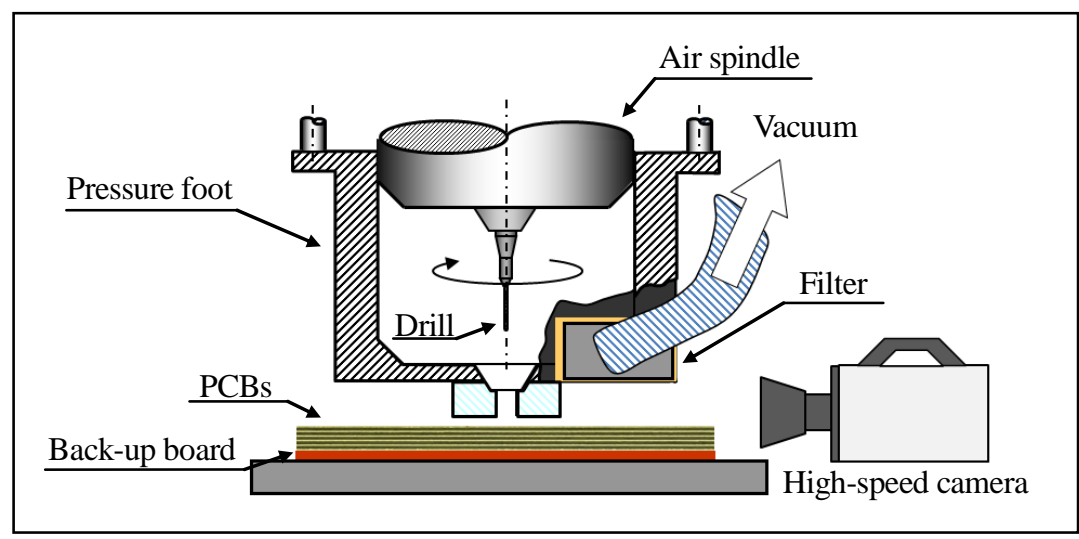

Fig. 2 Experimental setup of micro drilling test

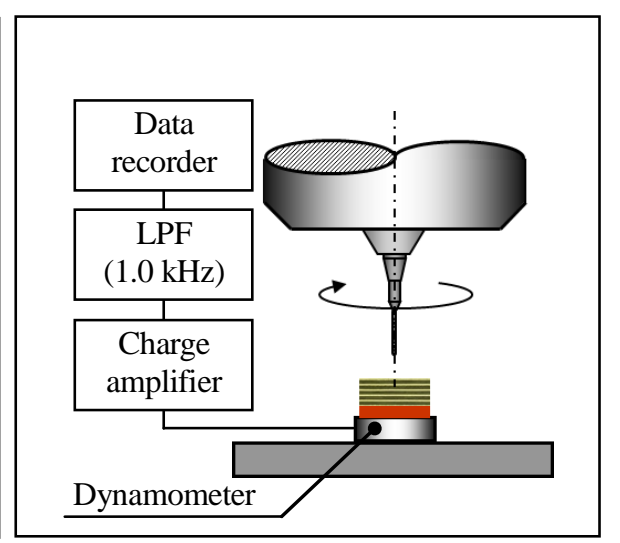

Fig. 3 Experimental setup of measuring cutting torque

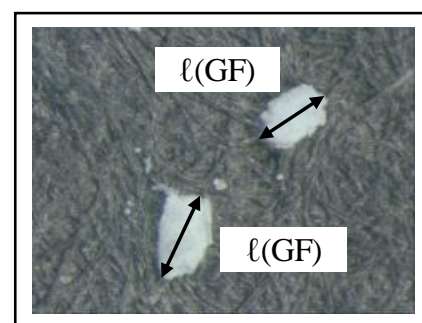

(a)

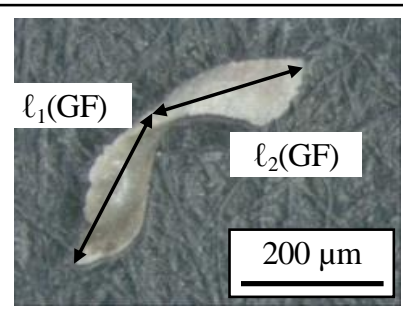

(b)

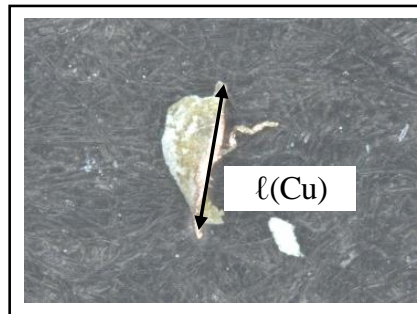

(a)

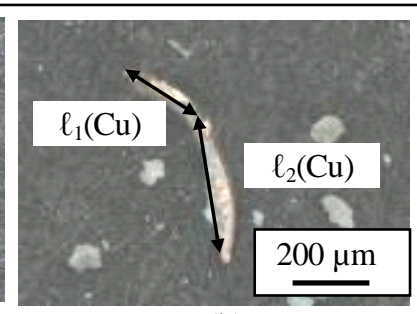

(b)

Fig. 4 Measurement of size of GFRP chips

表 2 は実験に用いるドリルの主な仕様を示す. 図 6 にドリルの外観写真を示す. ドリルはルーマ型ツイストド リルであり，GFRP が内装銅筞の端面に薄く付着するスミアの抑制および内壁粗さ向上に効果があるアンダーカ 
ットタイプである.アンダーカットタイプはドリルマージン部の長さが短く，穴内壁との接触長さが短い. この ため穴あけ加工時の被削材との摩擦が低減され, 穴内壁の品質向上に効果があり生産現場で多く採用されている. ドリル材質は生産現場で多く採用されている超硬合金(K10 相当)のコーティングなしを用いた．表 3 は本実験に 用いた切削条件を示す。ドリル回転数が切りくず排出性におよぼす影響を検討するためにドリルメーカー推奨条 件であるドリル回転数 $100 \times 10^{3} \mathrm{~min}^{-1}$ を基準とし $20 \times 10^{3} \mathrm{~min}^{-1}, 100 \times 10^{3} \mathrm{~min}^{-1}$ および $160 \times 10^{3} \mathrm{~min}^{-1}$ の 3 種類の回転数 を用いる. ドリル送り量はドリル折損が生じにくい最大送り量 $0.02 \mathrm{~mm} / \mathrm{rev}$ を用いる. 切削油剤は用いていない. PCB スルーホール穴あけ加工では，バリの発生抑制や穴位置精度などの加工穴品質の向上を目的に，ドリルの侵 入側である PCB 最上層の銅筞層上面にエントリーボードという当て板が用いられるが, 本実験では切りくず排出 状況や切りくず観察を単純化するためにエントリーボードは用いていない.

図 7 は, ドリル逃げ面の最大摩耗幅 $\mathrm{V}_{\mathrm{B}}$ の測定方法を示す. 本研究においては, 以下ドリルの逃げ面摩耗を工 具摩耗，ドリル逃げ面の最大摩耗幅 $V_{\mathrm{B}}$ を工具摩耗幅 $\mathrm{V}_{\mathrm{B}}$ と呼ぶ. 工具摩耗幅 $\mathrm{V}_{\mathrm{B}}$ はドリルの外周部における新品 ドリルの切れ刃稜線からの摩耗幅であり，2 枚の切れ刃について測定し平均值を工具摩耗幅 $\mathrm{V}_{\mathrm{Bm}}$ とする。 なお， 本実験において用いるドリルは，工具摩耗の影響を検討する場合以外の実験では，切削条件ごとにすべて新品ド リルを用いる。

Table 2 Specifications of micro drill

\begin{tabular}{c|c}
\hline Material & Tungsten carbide \\
\hline Diameter & $0.25 \mathrm{~mm}$ \\
\hline Flute length & $4.5 \mathrm{~mm}$ \\
\hline Helix angle & $45^{\circ}$ \\
\hline Point angle & $140^{\circ}$ \\
\hline Web thickness & $0.105 \mathrm{~mm}$ \\
\hline Overall length & $38.1 \mathrm{~mm}$ \\
\hline
\end{tabular}

Table 3 Cutting conditions

\begin{tabular}{c|c}
\hline Rotational speed & $20 \times 10^{3}, 100 \times 10^{3}, 160 \times 10^{3} \mathrm{~min}^{-1}$ \\
\hline Feed rate & $0.02 \mathrm{~mm} / \mathrm{rev}$ \\
\hline
\end{tabular}

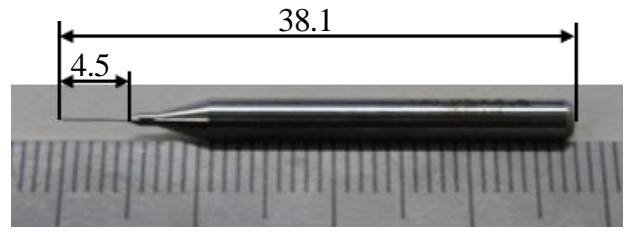

Fig. 6 Photograph of drill

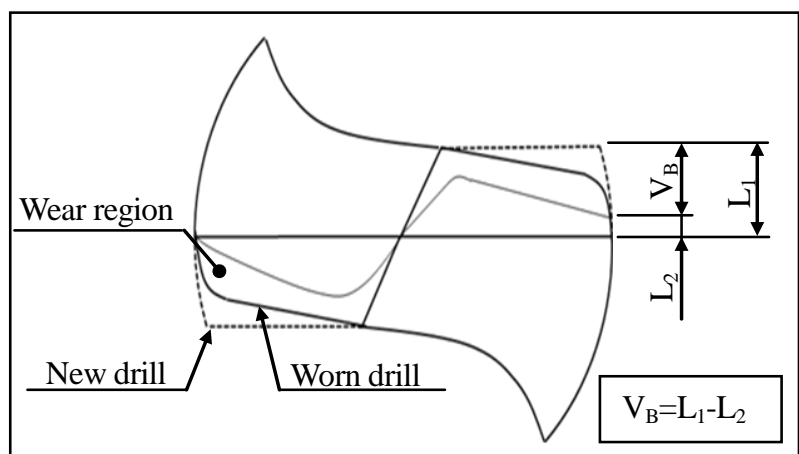

Fig. 7 Measurement of wear width of worn drill

\section{3. 実験結果と考察}

\section{$3 \cdot 1$ ドリル切れ刃稜線と被削材の接触状態が切りくず生成におよほす影響}

4 枚重ね PCB の穴あけ加工においては，穴深さに伴いドリル切れ刃稜線と被削材の接触状態が変化する. 4 枚 重ね PCB を構成するそれぞれの PCB は上から順に $\mathrm{n}$ 枚目 PCB（n=1～4）と呼ぶ. 図 8 は 4 枚重ね PCBの穴あけ 加工 1 サイクルにおける穴あけ過程において, ドリル切れ刃稜線と被削材の接触状態をパターン I からパターン IIIの 3 つに分類して示す. 図の中の1)～1512,ドリルチゼル部およびドリル肩部が 4 枚重ね PCB の銅箔層と GFRP 層の境界部を通過する位置を示す.なお(16) PCB の銅箔層とバックアップボードの境界部を通過する位置を示す.

パターン I はドリルチゼル部が 1 枚目 PCB の上側銅䇴層への接触開始位置からドリルチゼル部が 1 枚目 PCB の下側銅筞層への接触開始位置までの範囲（1)～(5)）である. 図 8 において(1)はドリルチゼル部が 1 枚目 PCB の 上側銅筞層への開始位置，(2)は 1 枚目 PCB の GFRP 層への接触開始位置を示す. (3)ドリル肩部が 1 枚目 PCB の上側銅筞層への開始位置，(4)ドリル肩部が 1 枚目 PCB の GFRP 層への接触開始位置を示す. (5)ドリルチゼ ル部が 1 枚目 PCB の下側銅箔層への接触開始位置を示す. (1)から(2)までは銅箔層のみの切りくずがドリルチゼル 
部付近の切れ刃で生成され，(2)から(4)までは銅簿層および GFRP 層の切りくずが同一切れ刃で生成される. (4)か ら(5)までは GFRP 層の切りくずのみが生成される.

パターン II は，ドリルチゼル部が $\mathrm{n}$ 枚目（n=1〜3）PCB の下側銅箔層への接触開始位置から，ドリルチゼル部 $(\mathrm{n}+1)$ 枚目 $\mathrm{PCB}$ の下側銅筞層への接触開始位置までの範囲（6)～(12) である. 図 8 において，6はドリルチゼ ル部が $\mathrm{n}$ 枚目 PCB の下側銅管層への接触開始位置，(7) $(\mathrm{n}+1)$ 枚目 PCB の下層銅䈃層への接触開始位置，8 は $(\mathrm{n}+1)$ 枚目 PCB の GFRP 層への接触開始位置を示す．91はドリル肩部が $\mathrm{n}$ 枚目 PCB の下側銅䈃層への接触 開始位置，10は $(n+1)$ 枚目 PCB の下側銅䈃層への接触開始位置，11 $(\mathrm{n}+1)$ 枚目 PCB の GFRP 層への接触 開始位置を示す. 12)はドリルチゼル部が $(\mathrm{n}+1)$ 枚目 PCB の下側銅䈃層への接触開始位置を示す. (6)から(11まで は，銅䇴層および GFRP 層の切りくずが同一切れ刃から同時に生成され，(11から(12までは GFRP 層の切りくずの みが生成される。

パターンIIIは，ドリルチゼル部が 4 枚目 PCB の下側銅䈃層への接触開始位置からドリル肩部が 4 枚目 PCB $の$

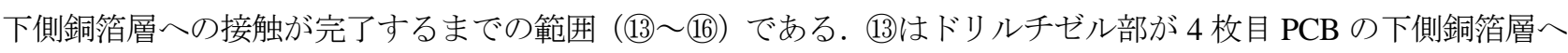
の接触開始位置，14は 4 枚目 PCB の下側銅䈃層への接触終了位置を示寸．15はドリル肩部が 4 枚目 PCB の下側 銅䈃層への接触開始位置, (16はドリル肩部が4枚目 PCB の下側銅箔層への接触完了位置を示寸. (13)から(15)までは, GFRP 層および銅箔層の切りくずが同一切れ刃から同時に生成される. (15から16までは, 銅䈃層およびのバック アップボード材の切りくずが生成される.

以上の検討結果より, PCB4 枚重ねの穴あけ加工は銅馢層, GFRP 層およびバックアップボード材からなる異材 質加工であり, 穴あけ加工 1 サイクルの穴あけ過程においてはドリル切れ刃稜線と被削材である PCB との接触状 態によって同一切れ刃稜線上で同時に生成される切りくず材質は, 銅箔層のみの場合, GFRP 層のみの場合, 銅 䈃層と GFRP 層の場合，および銅馢層とバックアップボード材の場合の 4 種類の切りくず生成パターンが生じて いる. 異材質の同一切れ刃上での同時加工は, 切れ刃稜線における切りくず流出速度や切りくず形状やドリル溝 内での切りくず排出性に大きな影響をおよぼすことが推察される. なお本研究においては PCB の切りくずについ て検討するためにバックアップボード材の切りくずについては検討から除外する.

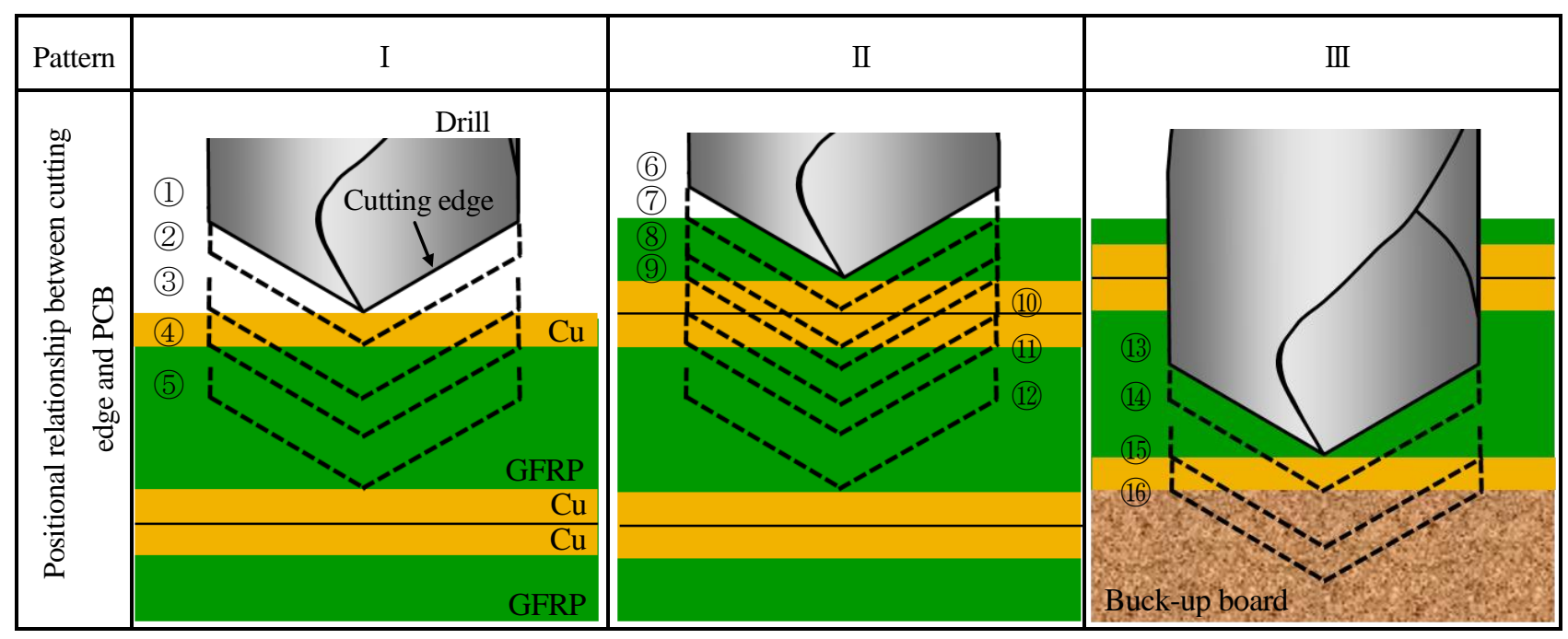

Fig. 8 Schematic illustration of positional relationship between cutting edge and PCB

\section{$3 \cdot 2$ ドリル回転数が切りくず排出性および切りくず形状におよほすす影響}

図 9 はドリル送り量を $0.02 \mathrm{~mm} / \mathrm{rev}$ 一定とし, ドリル回転数を $20 \times 10^{3} \mathrm{~min}^{-1}, 100 \times 10^{3} \mathrm{~min}^{-1}$ および $160 \times 10^{3} \mathrm{~min}^{-1}$ 人 変化させた場合における PCB 穴あけ加工1サイクルの切りくず排出状況を, 高速度カメラを用いて撮影した静止 画像を示す. ドリルは工具摩耗の影響を除くために切削条件ごとに新品ドリルを用いている. 図 9 において, 左 側から 1 列目は穴あけ加工 1 サイクルの模式図を示しており．上から下に向かって穴あけ加工が進行している状 況を示す. 左側から 2 列目, 3 列目, 4 列目はドリル回転数が $20 \times 10^{3} \mathrm{~min}^{-1}, 100 \times 10^{3} \mathrm{~min}^{-1}, 160 \times 10^{3} \mathrm{~min}^{-1}$ の場合で ある.最上段から 3 段目までは穴あけ過程であり．最下段は戻し過程を示している. 
図 9 の最上段は，穴あけ過程における加工穴表面からドリルチゼル部の穴深さが $0.4 \mathrm{~mm}$ 付近の切りくず排出状 況を示す．ここでは 1 枚目 PCB の GFRP 層穴あけ加工を行っており, 図 8 におけるパターン I の(4)から(5)の範囲 に対応寸る. ドリル回転数が $20 \times 10^{3} \mathrm{~min}^{-1}$ の場合（左側から 2 列目）は PCB1 枚目の上側銅筞層を穴あけ加工した 際に生成された銅筞切りくずが穴入口部付近においてドリルに巻きついており切りくず詰まりが生じていること がわかる．ドリル回転数が $100 \times 10^{3} \mathrm{~min}^{-1}$ の場合（左側から 3 列目）は，ドリル回転数が $20 \times 10^{3} \mathrm{~min}^{-1}$ の場合に比べ て銅管切りくずの巻き付きは少なく GFRP 切りくずが飛散していることがわかる. ドリル回転数が $160 \times 10^{3} \mathrm{~min}^{-1}$ の場合（左側から 4 列目）は，切りくず詰まりは発生しておらず GFRP の粒状の切りくずが加工穴外部へ飛散し ておりドリル回転数が $100 \times 10^{3} \mathrm{~min}^{-1}$ の場合に比べて切りくず排出性がさらに向上していることがわかる.

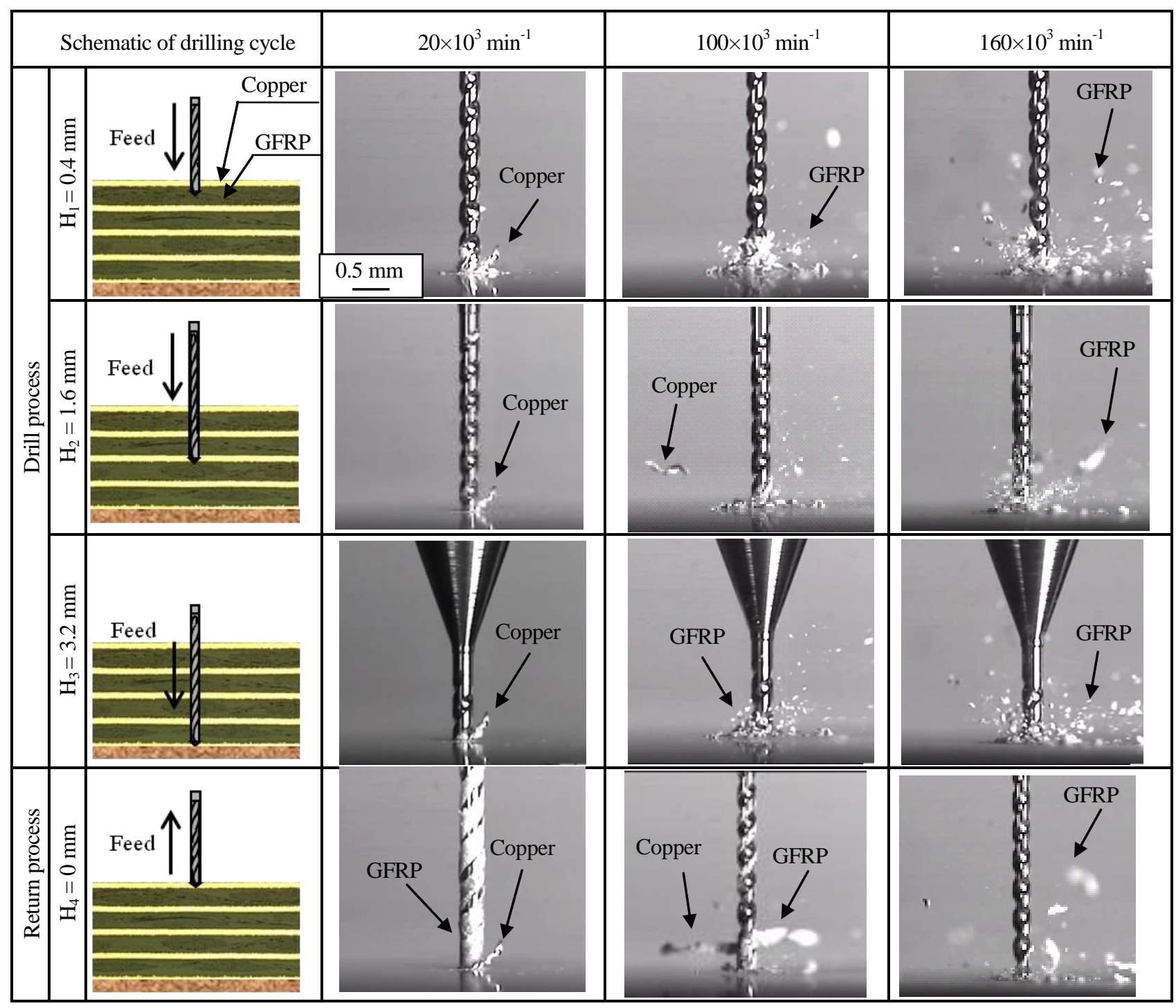

Fig. 9 Photographs of chip-evacuation with high-speed motion camera

図 9 の上から 2 段目は, 穴あけ過程において加工穴表面からドリルチゼル部の穴深さが $1.6 \mathrm{~mm}$ 付近の切りくず 排出状況を示す.ここでは 3 枚目 PCB の上側銅管層穴あけ加工を行っており, 図 8 におけるパターン II の7 7 から 8の範囲に対応する. 図 9 の上から 3 段目は, 穴あけ過程において加工穴表面からドリルチゼル部の穴深さが $3.2 \mathrm{~mm}$ 付近の切りくず排出状況を示す。ここでは 4 枚目 PCB の下側銅筞を穴あけ加工を行っており, 図 8 におけ るパターンIIIの(13)から(14)の範囲に対応する. ドリルチゼル部の穴深さが $1.6 \mathrm{~mm}$ 付近 (上から 2 段目) および $3.2 \mathrm{~mm}$ 付近 (上から 3 段目) では, いずれの場合もドリル回転数が $20 \times 10^{3} \mathrm{~min}^{-1}$ では銅箔切りくずが穴入口部付近におい 
てドリルに巻きついており切りくず詰まりが生じている. 一方, ドリル回転数が $100 \times 10^{3} \mathrm{~min}^{-1} お よ ひ ゙ ~ 160 \times 10^{3} \mathrm{~min}^{-1}$ の場合はドリル回転数の増大に伴い切りくず排出性が向上していることが確認される.

図 9 の上から 4 段目は, 穴あけ完了後のドリルの戻し過程である. ドリル回転数が $20 \times 10^{3} \mathrm{~min}^{-1}$ の場合は, 穴あ け過程において排出されなかった GFRP 切りくずがドリル溝を完全に覆うように付着しており切りくず詰まりが 生じているのがわかる. ドリル回転数が $100 \times 10^{3} \mathrm{~min}^{-1}$ の場合は，加工穴外部一排出されなかった銅筞切りくずお よび GFRP 切りくずがドリル先端付近に巻き付いているものの, ドリル回転数が $20 \times 10^{3} \mathrm{~min}^{-1}$ の場合に見られたよ うなドリル溝を完全に覆う状況は発生していない. ドリル回転数が $160 \times 10^{3} \mathrm{~min}^{-1}$ の場合は, 切りくず巻き付きお よびドリル溝に付着する切りくずはみられず穴あけ過程での切りくず排出性が良好であることがわかる．高速度 カメラを用いた切りくず排出状況の動画観察からも，ドリル送り量を $0.02 \mathrm{~mm} / \mathrm{rev}$ 一定としドリル回転数が $20 \times$ $10^{3} \mathrm{~min}^{-1}$ から $160 \times 10^{3} \mathrm{~min}^{-1}$ の範囲においては，ドリル回転数が高くなるに伴い切りくず排出性が良好であること が確認されている.

図 10 はドリル送り量を $0.02 \mathrm{~mm} / \mathrm{rev}$ 一定とし，ドリル回転数が $20 \times 10^{3} \mathrm{~min}^{-1}, 100 \times 10^{3} \mathrm{~min}^{-1}$ および $160 \times 10^{3} \mathrm{~min}^{-1}$ 一変化させた場合の GFRP 切りくず写真を示す. ドリル回転数が高くなるに伴い小さな粒形状の GFRP 切りくず が排出されており，ドリル回転数が低くなるに伴い大きな塊状の GFRP 切りくずが排出されている. 特に，ドリ ル回転数が $20 \times 10^{3} \mathrm{~min}^{-1}$ の場合はドリル溝形状が転写されたような湾曲した塊状の切りくずが観察される. 高速度 カメラを用いた切りくず排出状況の観察において $20 \times 10^{3} \mathrm{~min}^{-1}$ の場合は切りくず排出性が悪く, 図 9 に示すように 戻し過程においてドリル溝に付着した切りくず詰まりが観察されており，これらの GFRP 切りくずがドリル回転 中にドリル溝から剥離し脱落したしたものと推察される.

図 11 はドリル送り量を $0.02 \mathrm{~mm} / \mathrm{rev}$ 一定とし，ドリル回転数を $20 \times 10^{3} \mathrm{~min}^{-1}, 100 \times 10^{3} \mathrm{~min}^{-1}$ および $160 \times 10^{3} \mathrm{~min}^{-1}$ 一変化させた場合における銅箔切りくず写真を示す．いずれのドリル回転の場合においても，銅箔切りくずは GFRP 切りくず形状に比べて細長い形状である.これは GFRP 切りくずの場合はき裂型切りくずに分類されるの に対して，銅䇴切りくずの場合は流れ型切りくずに分類されるためである.さらには，いずれのドリル回転の場 合においても，銅箔切りくずには GFRP 切りくずの付着が観察される. これは図 8 に示したように, 銅䈃層が切 削される場合は，ドリルの同一切れ刃稜線で GFRP層も同時に生成されるためであると推察される.

図 12 はドリル送り量を $0.02 \mathrm{~mm} / \mathrm{rev}$ 一定とし，ドリル回転数が GFRP 切りくず長さ $\ell_{\mathrm{m}}(\mathrm{GF})$ および銅馢切りくず 長さ $\ell_{\mathrm{m}}(\mathrm{Cu})$ におよぼす影響を示す. GFRP 切りくずの場合はドリル回転数が高いほど切りくず長さ $\ell_{\mathrm{m}}(\mathrm{GF})$ は短く, ドリル回転数が低いほど切りくず長さ $\ell_{\mathrm{m}}(\mathrm{GF})$ は長いことがわかる. 銅筞切りくず $\ell_{\mathrm{m}}(\mathrm{Cu})$ の場合は $\mathrm{GFRP}$ 切りくず のようなドリル回転数の変化に伴う切りくず長さ $\ell_{\mathrm{m}}(\mathrm{GF})$ の変化はほとんどみられない.

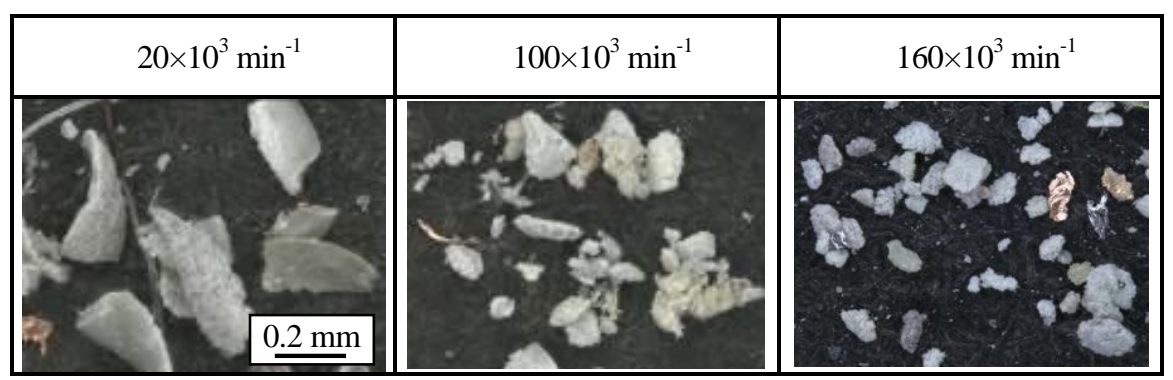

Fig. 10 Photographs of GFRP chips

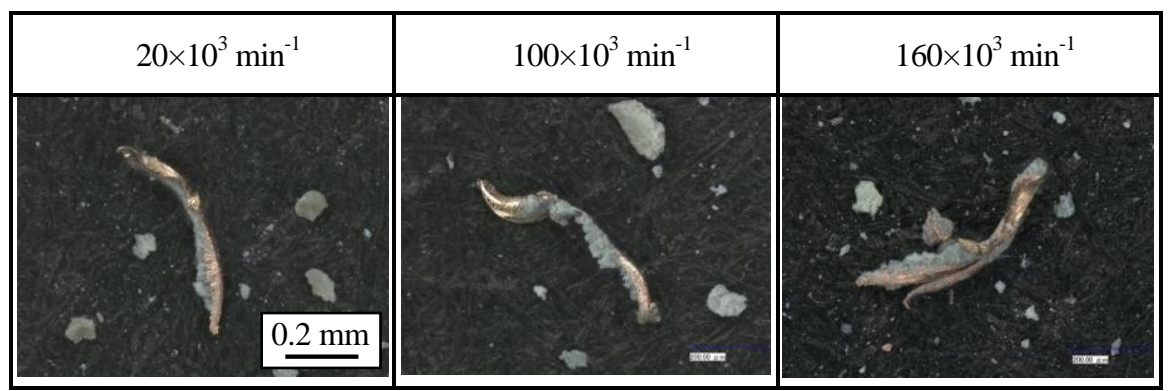

Fig. 11 Photographs of copper chips 


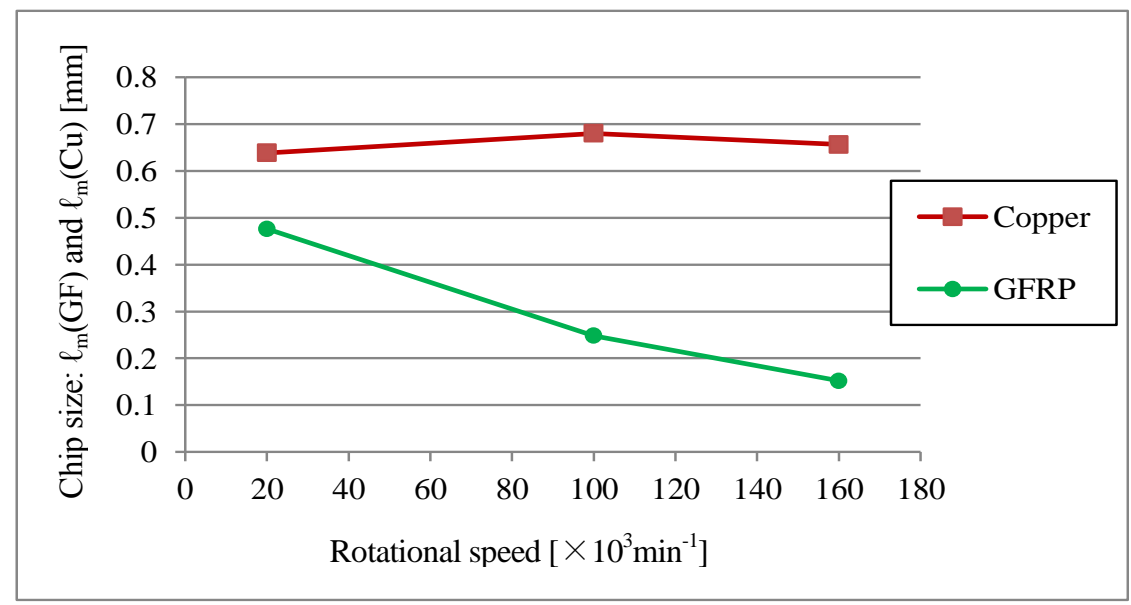

Fig. 12 Relationship between rotational speed and chip size

以上のように，高速度カメラを用いた切りくず排出状況の観察および顕微鏡を用いた切りくず観察から，本実 験条件の範囲ではドリル回転数が切りくず排出性や切りくず形状に影響をおよぼしていることがわかる．具体的 には，ドリル回転数が高くなるに伴い切りくず排出性は向上し，GFRP 切りくず形状は細かい粒形状へ変化し切 りくず長さは短くなる，一方，ドリル回転数が低くなるに伴い切りくず排出性は悪化し，GFRP 切りくず形状は 大きな塊形状へ変化し切りくず長さは長くなる.

図 13 は穴深さ $\mathrm{H}$ でのドリル溝内の切りくず排出状況の模式図およびドリル溝面を展開した切りくず排出モデ ル図を示す．図 13 (a)は切りくず排出性の良好なドリル回転数の高い場合であり，図 13 (b)は切りくず排出性の悪 化しているドリル回転数の低い場合である. 切りくず排出を阻害する力 $\mathrm{F}_{1}$ の主なものは，切りくず表面とドリル 溝表面との摩擦力および切りくず表面と加工穴内壁面との摩擦力であると考えられる. 図 13 (a)および図 13 (b) に示す $\theta$ はドリルねじれ角であり，本実験では $\theta=45^{\circ}$ である.

ドリル回転数 $160 \times 10^{3} \mathrm{~min}^{-1}$ に対して $100 \times 10^{3} \mathrm{~min}^{-1}, 20 \times 10^{3} \mathrm{~min}^{-1}$ ヘとドリル回転数が低くなるに伴い, ドリル切 れ刃稜線において生成される切りくず速さは遅くなり, ドリル溝内の切りくずが押し出される速さも遅くなる. ドリル溝内での切りくずは一定速さで移動しているのではなく, 静止したり動いたりしており, 切りくず表面と ドリル溝表面との摩擦力および切りくず表面と加工穴内壁面との摩擦力には静摩擦と動摩擦の両方が混在してい る. ドリル回転数が低くなると, ドリル溝内の切りくずは低速で加工穴入り口に向かって排出されるため, 切り くずがドリル溝内で静止する可能性が大きくなり, 静摩擦の比率は大きくなる. よって, ドリル回転数が低くな るに伴い加工穴深さ $\mathrm{H}$ における切りくず排出を阻害する力 $\mathrm{F}_{1}$ は大きくなる. すなわち，ドリル回転数が高くな るに伴い切りくず排出性は良好になり，ドリル回転数が低くなるに伴い切りくず詰まりが生じやすく，切りくず 排出性は悪化すると考えられる.

切りくず詰まりが発生しない浅穴加工では，ドリル回転数の大小に関わらずドリル切れ刃稜線で生成される GFRP 切りくず形状は小さな粒形状であることを確認している. 図 13(a)(b)においてドリル切れ刃稜線付近に存在 している GFRP 切りくず(GFRP chips near cutting edge)は, 切りくず詰まりの影響を受けていない小さな粒形状の GFRP 切りくずである. 図 13(a)はドリル回転数が高い場合を示す. ドリル切れ刃稜線で生成された小さな粒形状 の GFRP 切りくずは塊形状に変化することなく排出されており, ドリル切れ刃稜線付近に存在する GFRP 切りく ずとドリル溝内を流れる GFRP 切りくずは同じ大きさで表している. 図 13(b)はドリル回転数が低い場合を示す. ドリル溝内の切りくず詰まりによってドリル切れ刃稜線で生成された小さな粒形状の GFRP 切りくず同士が圧着 することで大きな塊形状一と変化する. 図13(b)ではドリル切れ刃稜線付近に存在する切りくずに比べてドリル溝 内の切りくずは大きな形状で表している．また，GFRP 切りくずが圧着され GFRP 切りくず間の隙間が小さくな ることで銅筞切りくず間の距離は短くなっている. 図 13(a)(b)に示す銅箔切りくずおよび GFRP 切りくずの大き さは図 10,11,12 に示す切りくずの大きさを反映している.

図 13(a)および図 13(b)においてドリル切れ刃稜線において生成される切りくずの押し出し力を $\mathrm{F}_{2}$ とすると, ド 
リル一回転あたりにドリル切れ刃稜線で生成される切りくず生成量はドリル回転数の大小に関わらず一定である ため, $\mathrm{F}_{2}$ はドリル回転数の影響は受けない. ドリル溝内の切りくずを加工穴外部に排出させるためには， $\mathrm{F}_{2}$ は切 りくず排出を阻害する力 $\mathrm{F}_{1}$ に比べて大きい必要があり， $\mathrm{F}_{1}$ が大きくなるに伴い切りくず詰まりが生じやすい. 切 りくず詰まりが発生すると, 切りくず表面とドリル溝表面とのドリル回転方向の摩擦力および切りくず表面と加 工穴内壁面とのドリル回転方向の摩擦力が増大し切削トルクが上昇する.

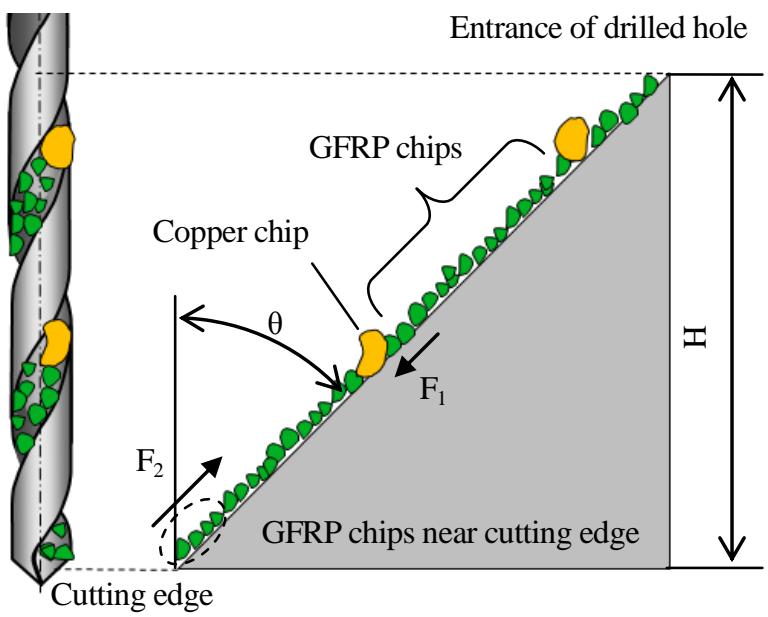

(a) high rotational speed

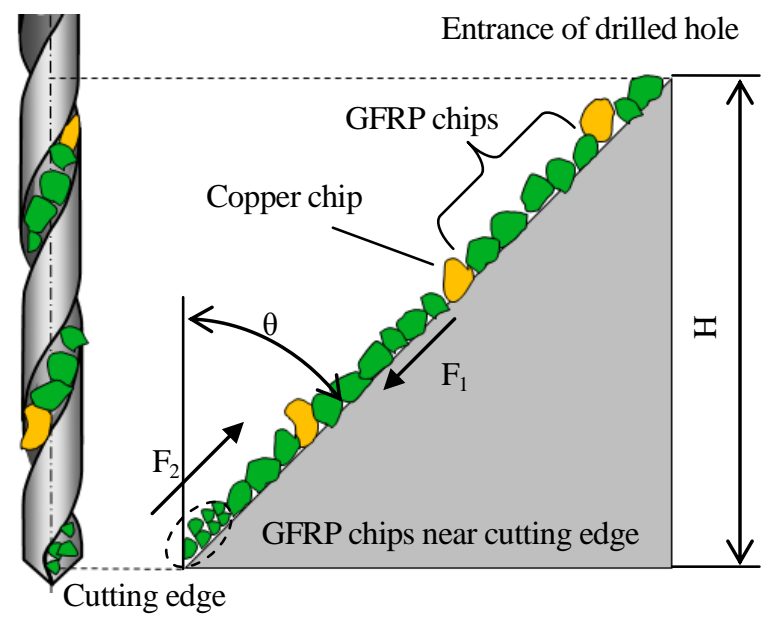

(b) low rotational speed

Fig. 13 Schematic illustration of chip-evacuation

\section{$3 \cdot 3$ ドリル回転数が切削トルクにおよほす影響}

図 14 は，ドリル送り量を $0.02 \mathrm{~mm} / \mathrm{rev}$ 一定としドリル回転数が $20 \times 10^{3} \mathrm{~min}^{-1}$ および $160 \times 10^{3} \mathrm{~min}^{-1}$ の場合での穴 あけ過程における加工穴深さに対する切削トルクの推移を示す．ドリル回転数が $20 \times 10^{3} \mathrm{~min}^{-1}$ の場合は，加工穴 深さが 3 枚目 PCB の GFRP 層を穴あけ加工している途中から切削トルクが上昇し，4 枚重ねの PCB を穴あけ完 了しバックアップボードを貫通した時点で最大切削トルク $\mathrm{T}_{\text {max }}=3.88 \times 10^{-3} \mathrm{Nm}$ に到達している. 高速度カメラを 用いた切りくず排出性の観察結果から加工穴深さが深くなるに伴い切りくず排出性が悪化しており，ドリル溝に 滞留した切りくずを穴外部へ排出するために切削トルクが上昇したものと考えられる.

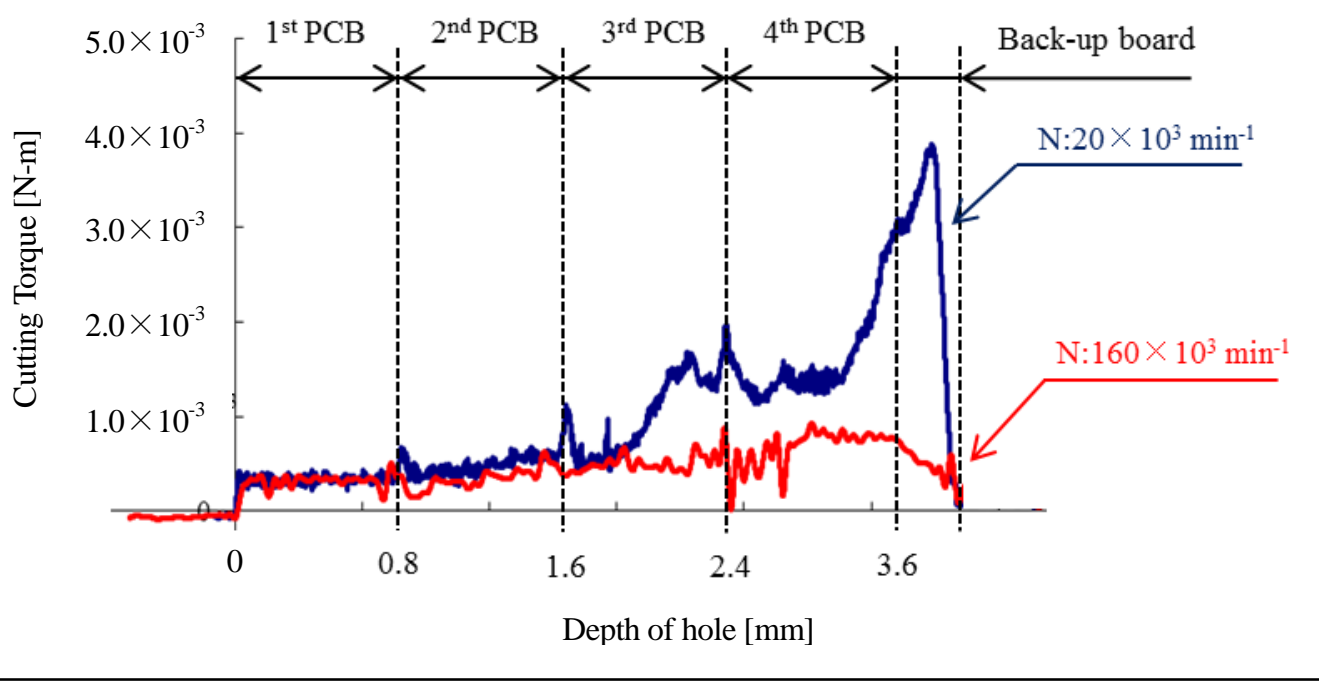

Fig. 14 Relationship between depth of hole and cutting torque 
一方，ドリル回転数が $160 \times 10^{3} \mathrm{~min}^{-1}$ の場合は，加工穴深さが深くなるに伴い切削トルクは上昇傾向にあるが， 切削トルク上昇の傾きはドリル回転数が $20 \times 10^{3} \mathrm{~min}^{-1}$ の場合に比べて緩やかである. 穴あけ加工中の最大切削卜 ルクは PCB4 枚目を穴あけ加工中の $\mathrm{T}_{\text {max }}=0.93 \times 10^{-3} \mathrm{Nm}$ であり, ドリル回転数が $20 \times 10^{3} \mathrm{~min}^{-1}$ での最大切削卜ル クに比べて約 $24 \%$ と低い值を示している. ドリル回転数および加工穴深さが切削トルクにおよぼす影響は，高速 度カメラを用いた切りくず排出性の観察結果とよく一致している. すなわち，切りくず排出性が悪化するに伴い 切削トルクが上昇していることがわかる. 図 15 は, ドリル送り量を $0.02 \mathrm{~mm} / \mathrm{rev}$ 一定としドリル回転数が $20 \times$ $10^{3} \mathrm{~min}^{-1}$ から $160 \times 10^{3} \mathrm{~min}^{-1}$ の範囲において穴あけ過程での最大切削トルク $\mathrm{T}_{\text {max }}$ および平均切削トルク $\mathrm{T}_{\mathrm{a}}$ におよ ぼすドリル回転数の影響を示す。ここで, 平均切削トルク $\mathrm{T}$ a は，穴あけ過程での加工穴深さにおけるそれぞれ の切削トルクの值を積分し，穴あけ深さで除した值と定義する.

以上のように，本実験条件の範囲では穴あけ加工中の最大切削トルクおよび平均切削トルクは，いずれもドリ ル回転数が高くなるに伴い低減傾向にある. 特に切りくず詰まりの影響を受けやすい最大切削トルク $\mathrm{T}_{\text {max }}$ の低減 割合が大きくドリル折損対策に効果があることがわかる．さらには，穴深さが深くなるに伴い切削トルクは上昇 しており切削トルクの変動は高速度カメラで観察される切りくず排出性の良否にほぼ対応している. すなわち, 切りくず排出が良好な場合は切削トルクの值は低くなり, 切りくず排出性が悪化し切りくず詰まりが生じると切 削トルクの值は増大する.

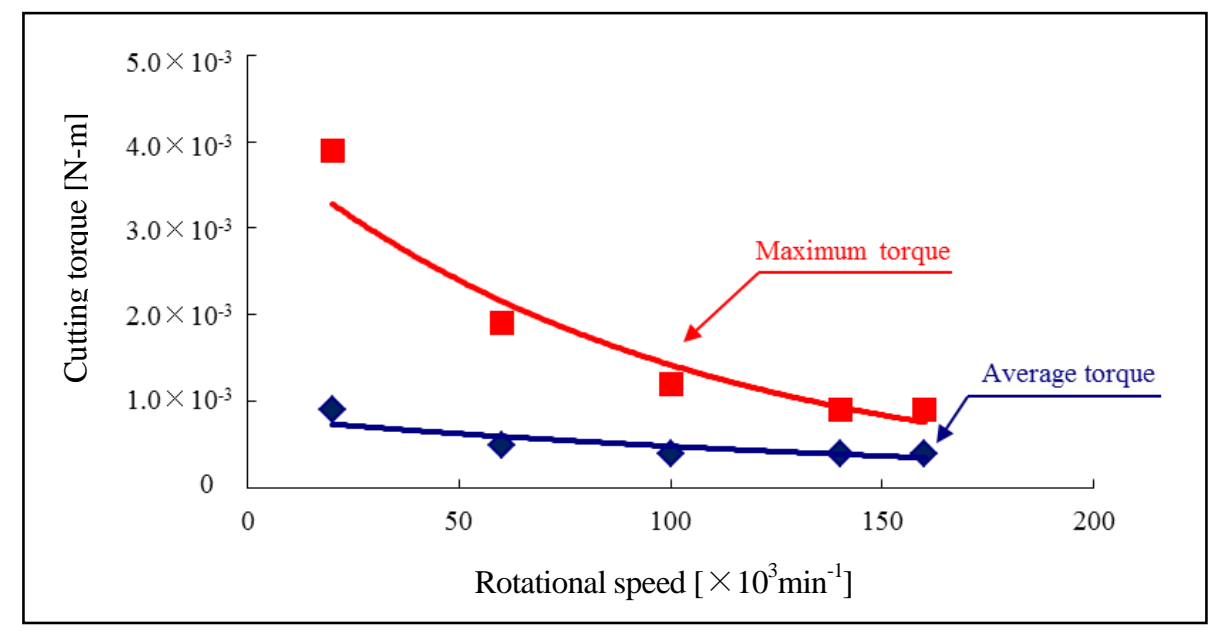

Fig. 15 Relationship between rotational speed and cutting torque

\section{$3 \cdot 4$ 工具摩耗が切りくず排出性および切りくず形状におよぼす影響}

新品ドリルを用いた実験ではドリル送り量 $0.02 \mathrm{~mm} / \mathrm{rev}$ の場合は上述のように，ドリル回転 $160 \times 10^{3} \mathrm{~min}^{-1}$ の場合 はドリル回転数 $100 \times 10^{3} \mathrm{~min}^{-1}$ および $20 \times 10^{3} \mathrm{~min}^{-1}$ の場合に比べて切りくず排出が良好であることがわかった. 切り くず排出性が良好である切削条件（ドリル送り量 $0.02 \mathrm{~mm} / \mathrm{rev}$ ，ドリル回転 $160 \times 10^{3} \mathrm{~min}^{-1}$ ）を用いて加工穴数 3000 穴までの穴あけ加工実験を行い工具摩耗が切りくず排出性や切りくず形状におよぼす影響を検討する.

図 16 は加工穴数が 1 穴, 1000 穴および 3000 穴加工後の工具摩耗写真を示寸. 加工数の増加に伴い工具摩耗が 増大しており，ドリル逃げ面においてドリル外周部が欠肉しているのがみてとれる．図 17 は，工具摩耗幅 $\mathrm{V}_{\mathrm{Bm}}$ の加工穴数に対する推移を示す. 加工数の増加に伴い工具摩耗幅 $\mathrm{V}_{\mathrm{Bm}}$ が増大している. 工具摩耗の増大に伴いド リル切れ刃稜線の丸み半径も増加傾向にあると推察され刃先稜線近傍では工具のすくい角は負角として作用する と考えられる.

図 18 は，ドリル回転数 $160 \times 10^{3} \mathrm{~min}^{-1}$, ドリル送り量 $0.02 \mathrm{~mm} / \mathrm{rev}$ の切削条件を用いて, 加工穴数が 1 穴目, 1000 穴目および 3000 穴目における PCB 穴あけ加工 1 サイクルの切りくず排出状況を, 高速度カメラを用いて撮影し た静止画像を示す．図において，左側 1 列目は穴あけ加工 1 サイクルの模式図を示しており．上から下に向かっ て穴あけ加工が進行している. 左側 2 列目，3列目，4列目は加工穴数が 1 穴目，1000 穴目および 3000 穴目の場 合である. 
図 18 において最上段から 3 段目までは穴あけ過程であり。最下段は戻し過程を示している．最上段から4段目 までに示すドリルチゼル部と加工穴表面からの穴深さとの位置関係は, 図 9 に示す位置関係とすべて同じである. 最上段は，穴あけ過程における加工穴表面からドリルチゼル部の穴深さが $0.4 \mathrm{~mm}$ 付近の切りくず排出状況を示 す. 加工穴数が 1 穴目, 1000 穴目および 3000 穴目のすべての場合において切りくず詰まりは生じておらず切り くず排出性は良好である. 一方，加工穴数が増加し工具摩耗が増大寸るに伴い，排出される GFRP 切りくずの大 きさが変化している．特に，加工穴数が 3000 穴目の場合では，加工穴数 1 穴目に比べて GFRP 切りくず粒形状 の大きさが大きくなっているのが特徵的である．高速度カメラを用いた動画観察からは切りくず排出詰まりは生 じておらず切りくず排出性は良好であることから，加工穴数 3000 穴目における GFRP 切りくずの粒形状が加工 穴数 1 穴目に比べて大きくなっているのは切りくず詰まりによる影響ではなく, 刃先稜線での切りくず生成時の GFRP 切りくずそのものが大きくなっていると考えられる.

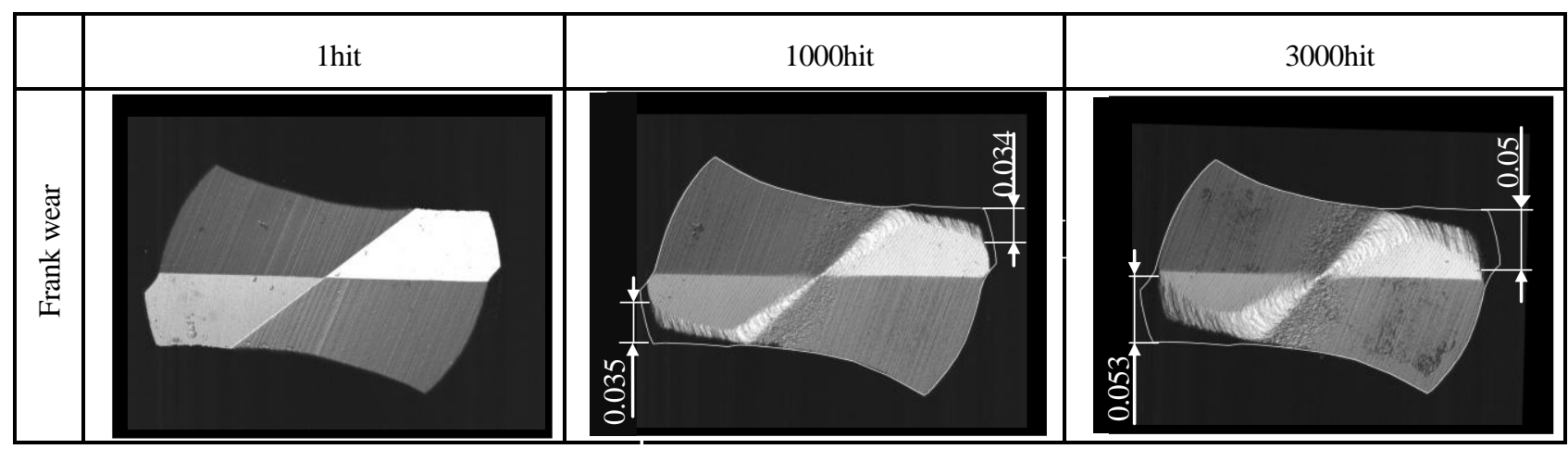

Fig. 16 Photographs of new drill and worn drill after 1000 and 3000 hits

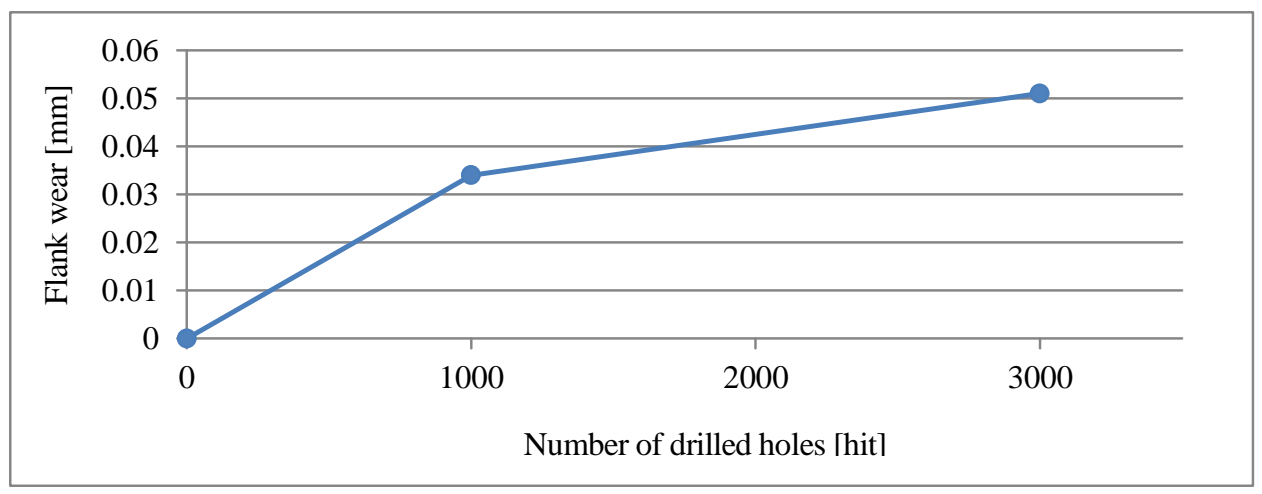

Fig. 17 Relationship between number of drilled hole and flank wear

図 18 の上から 2 段目および 3 段目は，穴あけ過程において加工穴表面からドリルチゼル部の穴深さが $1.6 \mathrm{~mm}$ 付近および $3.2 \mathrm{~mm}$ 付近の切りくず排出状況を示す. いずれの穴深さにおいても切りくず詰まりは生じておらず, 加工穴数の増加に伴って GFRP 切りくずの粒形状が大きくなる現象はみられない，一方，いずれの穴深さにおい ても加工穴数が増加し工具摩耗の増大に伴い GFRP 切りくずの粒形状の大きさは大きくなっている．これは，加 工穴深さ $0.4 \mathrm{~mm}$ 付近の場合と同様に, 切りくず詰まりによる影響ではなく, 刃先稜線での切りくず生成時の GFRP 切りくずそのものが大きくなっていると考える.

図 18 の上から 4 段目は，穴あけ完了後のドリルの戻し過程である. 加工穴数が 1 穴目，1000 穴目および 3000 穴目のいずれの場合においても切りくず巻き付きおよびドリル溝に付着する切りくずはみられず穴あけ過程での 切りくず排出性は良好であることがわかる.

図 19 は, 加工穴数 1 穴目, 1000 穴目および 3000 穴目に排出された GFRP 切りくず写真を示す. 加工穴数が増 加し工具摩耗が増大寸るに伴い GFRP 切りくずは切りくずの粒形状が大きくなっている. 切りくず形状から GFRP 層切りくずはき裂型に分類される. 工具摩耗の少ない切り刃が鋭利な場合は切れ刃から切れが進行する前 
方に向かうき裂が発生することで粒の小さい切りくずが生成されるが，工具摩耗が増大し切れ刃丸みが大きな場 合は切れ刃が進行する前下方に向かうき裂が発生し，粒の大きい切りくずが生成されると推察される. これらの GFRP 層切りくずの大きさの加工数に伴う変化は, 高速度カメラを用いた切りくず排出状況の観察結果と同様で ある. 図 20 は, 加工穴数 1 穴目，1000 穴目および 3000 穴目に排出された銅箔切りくず写真を示す. 切りくず形 状から銅䇴切りくずは流れ型に分類される. 加工穴数が増加し工具摩耗が増大寸るに伴い刃先丸みが大きくなる. これによりせん断ひずみ量が増大し，銅箔切りくずが加工硬化によって脆化し分断しやすいと推察される.

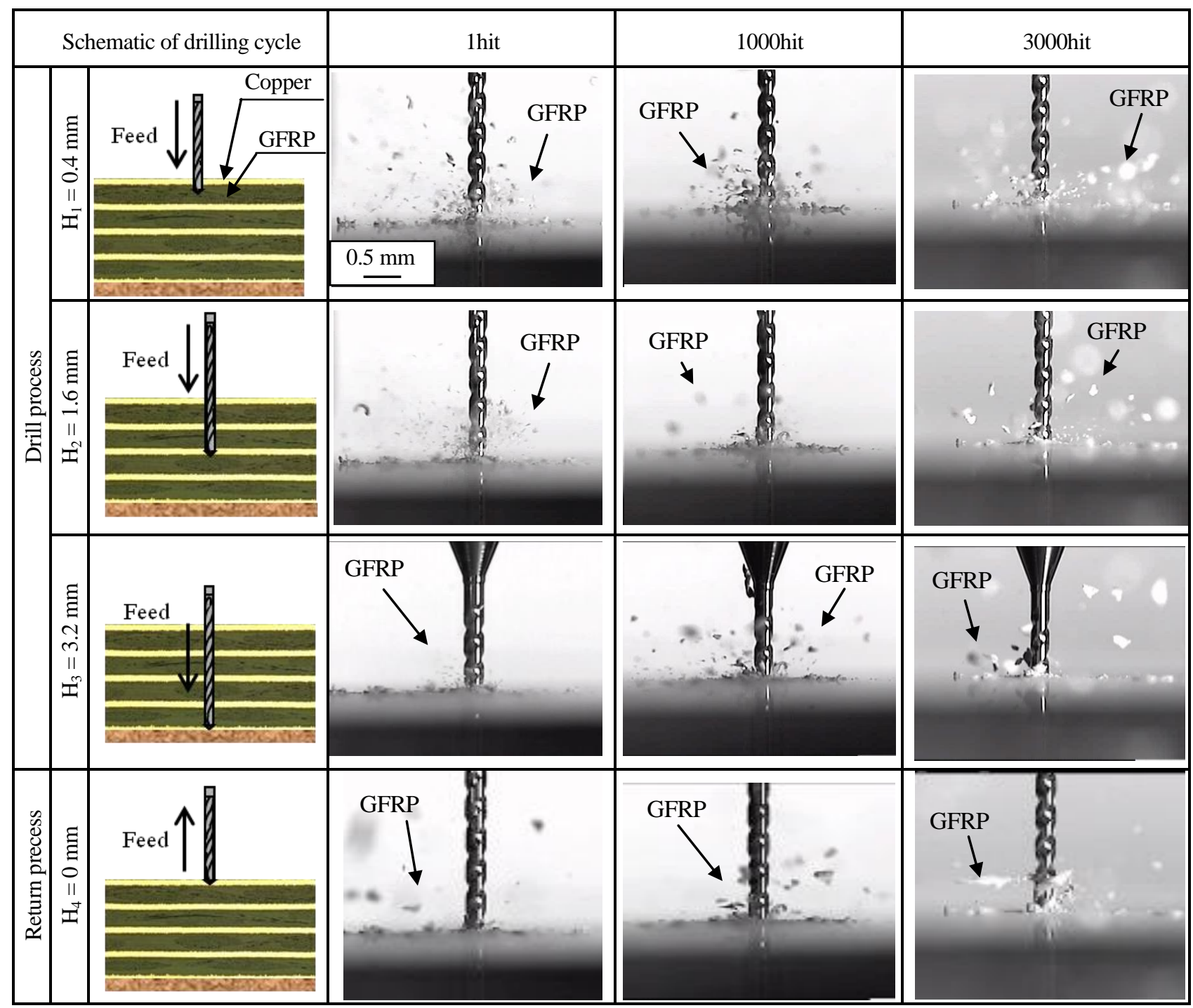

Fig. 18 Photographs of chip-evacuation with high-speed motion camera

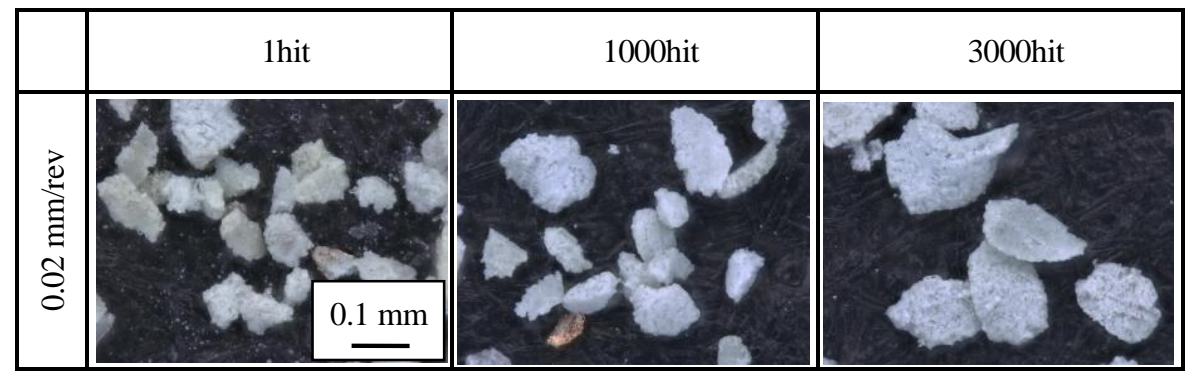

Fig. 19 Photographs of chip-evacuation with high-speed motion camera 


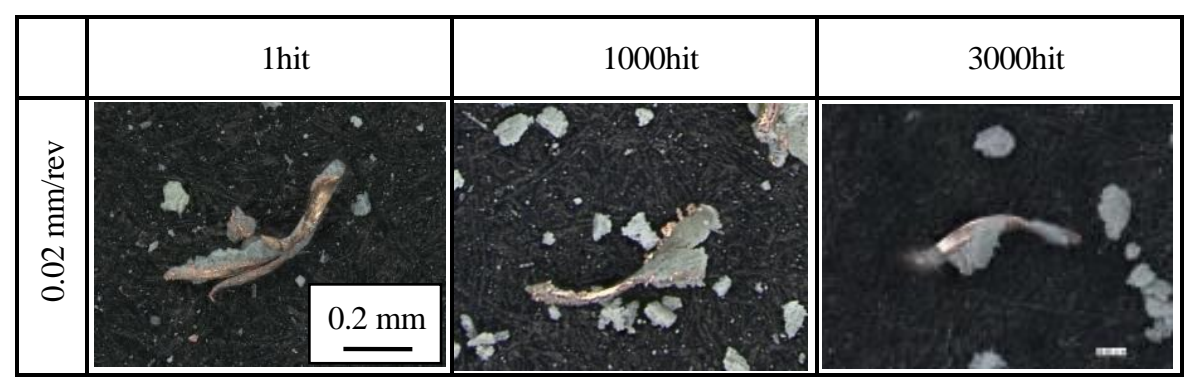

Fig. 20 Photographs of copper chips

図 21 は，工具摩耗の増大に伴う GFRP 切りくず長さ $\ell_{\mathrm{m}}(\mathrm{GF})$ および銅筞切りくず長さ $\ell_{\mathrm{m}}(\mathrm{Cu})$ の推移を示してい る. GFRP 切りくずの場合は工具摩耗増大に伴い切りくず長さが長くなっている. 銅䈃切りくずの場合は加工穴 数が増加し工具摩耗が増大するに伴い切りくず長さは短くなっている.

以上のように，高速度カメラを用いた切りくず排出状況の観察および顕微鏡を用いた切りくず観察から，工具 摩耗が増大するに伴い GFRP 切りくずの大きさが大きくなり, 銅筞切りくずは長さが短くなることがわかった. 工具摩耗が増大するに伴い刃先丸みが大きくなり，GFRP 切りくず形状や銅䇤切りくず長さに影響をおよぼして いると推察される. 図 19, 図 20 より切りくず生成後に切りくずが詰まって圧着される現象は観察されず，切り くず排出性が良好なため工具摩耗が切りくず排出性におよぼす影響は小さいと考えている.

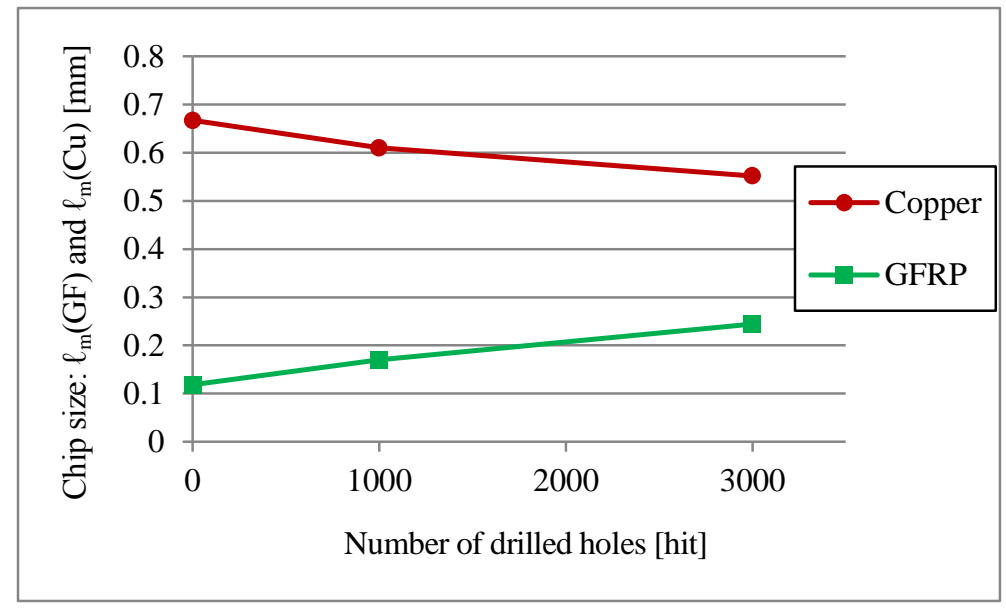

Fig. 21 Relationship between number of drilled holes and chip size

\section{4. 結言}

(1) PCB4 枚重ねの穴あけ加工は異材質加工であるため, ドリル切れ刃稜線と被削材である PCB との接触状態に よって, 銅筞切りくずのみ, GFRP 切りくずのみ, 銅箔切りくずと GFRP 切りくず, 銅箔切りくずとバック アップボード材の切りくずの 4 種類の切りくず生成パターンが生じ, 1 種類の材質を穴あけ加工する場合に 比べ切りくず形状や切りくず排出性が複雑である.

（2）ドリル回転数が低くなるに伴い切りくず詰まりが発生しやすく，切りくず排出性は悪化する. 切りくず詰ま りが発生した場合はドリル切れ刃稜線で生成された小さな粒形状の GFRP 切りくず同士がドリル溝内におい て圧着し，大きな塊形状となり切りくず長さは長くなる，一方，銅䇴切りくずはドリル回転数の変化に伴う 切りくず長さの変化はほとんどみられない.

（3）ドリル回転数が低くなるに伴い切りくず詰まりが発生しやすい. 切りくず詰まりが発生すると，切りくず表 面とドリル溝表面との摩擦力および切りくず表面と加工穴内壁面との摩擦力が増大し切削卜ルクが上昇する.

(4) 工具摩耗の増大に伴い切れ刃丸みが大きくなり, ドリル切れ刃稜線で生成される GFRP 切りくずは大きくな る. 他方, 銅䇴切りくずはせん断ひずみ量が増大し，切りくずが分断しやすくなる. ドリル回転数の高い領 域では，工具摩耗は切りくず排出性にほとんど影響をおよぼさない.

（5）ドリル回転数の増加に伴い切りくず排出性は向上する. ドリル一回転当たりの送り量が一定の場合，ドリル 
回転数を上げることが出来, ドリル送り速度を大きくすることが可能となり生産性は向上する. 一方, ドリ ル回転数の増加に伴い，切削温度上昇による加工穴内壁の樹脂の溶融や工具摩耗増大による切削性能低下が 懸念されるため検討が必要である. 切りくず排出性をさらに向上させるためにはドリル溝部への摩擦係数の 低いコーティング材の採用などが考えられる.

\section{文献}

大幸洋一，寺林隆夫，桝田正美，プリント基板の小径ドリル加工（第 1 報）一切削抵抗からみた切りくず排出機 構の解明一, 精密工学会誌, Vol.60, No.12 (1994), pp.1796-1800.

Heineman, R., Barrow, S.H.G. and Petuelli, G., The Performance of Small Diameter Twist Drills in Deep-Hole Drilling, Transaction of the ASME, Journal of Manufacturing Science and Engineering, Vol.1280, No.11 (2006), pp.884-892. 岩田一明, 森脇俊道, 星川雅之, 高速微小深穴ドリル加工の基礎的研究, 精密機械, Vol.49, No.2 (1982), pp.240-246. Mellinger, J.C., Ozdoganlar, O.B., Devor, R.E. and Kapoor, S.G., Modeling Chip-Evacuation Forces in Drilling for Vatious Flute Geometries, Transactions of the ASME, Journal of Manufacturing Science and Engineering, Vol.125, No.8 (2003), pp.405-415.

中山一雄, 小川誠, 切りくず形状から見たねじれ刃ドリルの切削性能, 精密機械, Vol.43, No.508 (1977), pp.427-432. 大久保修, 稲崎一郎, 青山藤詞郎, 清水哲, 微小径ドリルの折損原因の究明と折損予知に関する研究, 日本機械 学会論文集Ｃ編，Vol.51, No.471 (1985), pp.2929-2935.

小野元久, 菅原章, 矢野宏, 微小径ドリル加工に関する研究（第 1 報）一切削抵抗の測定について一, 精密工学 会誌，Vol,58, No.8 (1992), pp.1345-1350.

Subramanian, K. and Cook, N.H., Sensing of Drill Wear and Prediction of Drill Life, Transactions of the ASME, Journal of Engineering for Industry, Vol.99, No.295 (1977), pp.295-301.

渡邊英人, 津坂英夫, 栘田正美，プリント配線板における高速微小穴あけ加工一PCB 構成材料のドリル折損への 影響一，精密工学会誌, Vol.75, No.12 (2009), pp.1428-1433.

\section{References}

Daikoh, Y., Terabayashi, T. and Masuda, M., Micro drilling of printed circuit boards (1st Report) - Cutting Force and Chip Flow Mechanism-, Journal of the Japan Society of Precision Engineering, Vol.60, No.12 (1994), pp.1796-1800 (in Japanese).

Heineman, R., Barrow, S.H.G. and Petuelli, G., The performance of small diameter twist drills in deep-hole drilling, Transaction of the ASME, Journal of Manufacturing Science and Engineering, Vol.1280, No.11 (2006), pp.884-892.

Iwata, K., Moriwaki, T. and Hoshikawa, M., Fundamental study of high speed micro deep drilling, Journal of the Japan Society of Precision Engineering, Vol.49, No.2 (1982), pp.240-246 (in Japanese).

Mellinger, J.C., Ozdoganlar, O.B., Devor, R.E. and Kapoor, S.G., Modeling chip-evacuation forces in drilling for various flute geometries, Transactions of the ASME, Journal of Manufacturing Science and Engineering, Vol.125,No.8 (2003), pp.405-415.

Nakayama, K. and Ogawa, M., Cutting performance of twist drills in relation to the shape of chip produced, Journal of the Japan Society of Precision Engineering, Vol.43, No.508 (1977), pp.427-432 (in Japanese).

Okubo, O., Inasaki, I, Aoyama. T. and Shimizu T., A study on the cutting tool breakage and its prediction in micro hole drilling, Transactions of the Japan Society of Mechanical Engineers, Series C, Vol.51, No.471 (2009), pp.2929-2935 (in Japanese).

Ono, M., Sugawara, A. and Yano, H., Study on micro drill machining (1st Report) - On the measurement of cutting forceJournal of Japan Society for Precision Engineering, Vol.58, No.8 (1992), pp.1345-1350 (in Japanese).

Subramanian, K. and Cook, N.H., Sensing of drill wear and prediction of drill life, Transactions of the ASME, Journal of Engineering for Industry,Vol.99, No.295 (1977), pp.290-301.

Watanabe, H., Tsuzaka, H. and Masuda, M., High-speed micro drilling on printed circuit boards - Influence of PCB composite material on drill breakage--, Journal of the Japan Society for Precision Engineering, Vol.75, No.12 (2009), pp.1428-1433 (in Japanese). 